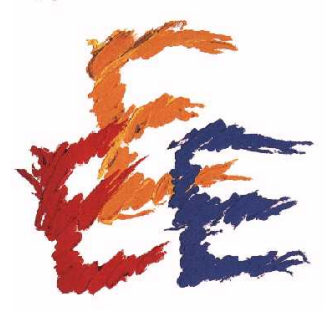

Fondazione Eni Enrico Mattei

\title{
Does Breed Matter to Cattle Farmers and Buyers? Evidence from West Africa
}

\author{
M.A. Jabbar* and M.L. Diedhiou*
}

NOTA DI LAVORO 110.2001

DECEMBER 2001
SUST - Sustainability Indicators and Environmental Evaluation

*International Livestock Research Institute (ILRI), Addis Ababa, Ethiopia

This paper can be downloaded without charge at:

The Fondazione Eni Enrico Mattei Note di Lavoro Series Index: http://www.feem.it/web/activ/_activ.html

Social Science Research Network Electronic Paper Collection: http://papers.ssrn.com/abstract $=297082$ 


\section{SUMMARY}

World agriculture is based on a small number of animal species and a decreasing number of breeds within each species. Several breeds of West African shorthorn cattle (Bos taurus brachyceros) are now at high risk of extinction due to interbreeding. The West African shorthorn breeds are particularly important resources because of their superior abilities to resist diseases, particularly trypanosomosis, and be productive under high humidity, heat stress, water restriction and with poor quality feed. An analysis of farmers' breeding practices and breed preferences in a sample area in southwest Nigeria confirmed a strong trend away from trypanotolerant breeds, especially Muturu, and identified the traits farmers find least desirable in these breeds relative to zebu (Bos indicus) breeds. An analysis of cattle market prices found that buyers have preferences for specific breeds for specific purposes and that though in general price differences due to breed are small, in some cases buyers pay significantly different prices for certain breeds consistent with their preferences. The best hopes for increased utilization of breeds at risk such as Muturu is likely in other areas of West Africa, for example in southeast Nigeria, where the Muturu is better suited to the farming systems and there is a large market for this breed to provide incentives.

Keywords: Cattle breeds, market prices, farmer preferences, genetic resources, conservation 
An hedonic approach is used to analyse farmers' breeding practices and breed preferences in southwest Nigeria. They confirm a strong trend away from trypanotolerant breeds, especially Muturu, and identify the traits farmers find least desirable in these breeds relative to other zebu breeds. Results suggest that implementing a conservation/sustainable use strategy for breeds at risk such as Muturu is likely to be best in other areas of West Africa; for example in southeast Nigeria where trypanosomosis remains a constraint, where the Muturu is better suited to the farming systems and where a large market for this breed continues to exist. 


\section{CONTENTS}

Introduction 2

Data source and methodology $\quad 4$

The study area 4

Household sample and data 5

Logit analysis of breed preference rating $\quad 7$

Market data 8

Implicit price analysis 9

Results and discussion $\quad 10$

Farmers' present and past breeding $\quad 10$

practices

Breed preference rating results $\quad 11$

Results of market and price analysis $\quad 13$

Conclusions and implications of findings $\quad 16$

References $\quad 18$ 


\section{Introduction}

There is an increasing global concern about the potential long-term consequences of loss of plant and animal genetic diversity and the need to conserve genetic resources. The world's animal agriculture is dependent upon about 40 species of mammals and birds, each with a great pool of genetic diversity. With the spread of domesticated animal agriculture across the planet during the last 10,000 to 12,000 years, different species of animals adapted to a wide range of environmental conditions and developed specialised strains and traits, many of which have become extinct or are now in danger of extinction. It has been suggested that globally 618 breeds of domestic animals have already become extinct (Hall and Ruane,1993) and in Europe one third of the surviving 737 distinct breeds of livestock are in danger of extinction (Cunningham, 1992).

A recent survey in sub-Saharan Africa revealed that out of 145 cattle breeds identified, 47 (32\%) were considered to be at risk of extinction, and $22(13 \%)$ previously recognised in the continent have already become extinct (Rege, 1999). The sub-humid and humid zones of West and Central Africa, the primary focus of this paper, is the home of some of these extinct breeds and the breeds at risk of extinction. These breeds at risk have developed, over the centuries since their predecessors were introduced into West and Central Africa, the ability to survive and be productive in areas of high humidity, heat stress, water restriction and poor quality feed, and more importantly low to moderate trypanosomosis risk, hence are considered to be trypanotolerant. The Bos taurus breeds also reportedly have superior levels of resistance to other diseases e.g., streptothricosis, ticks and tick-borne diseases, helminthosis high humidity, heat stress, water restriction and poor quality feed (Murray et al., 1990; d'Ieteren, 1994; Rege, 1999). These superior adaptive abilities make these breeds valuable for further livestock development in West and Central Africa and other harsh environments around the world. Achieving this goal will require conservation and 
improvement of the genetic resources carried by these breeds under risk.

The main threat of extinction for these breeds is interbreeding, especially with the humped Bos indicus breeds that have moved into the sub-humid and humid regions of West and Central Africa during the last 30 years. High population pressure and periodic droughts in the arid and semi-arid areas have prompted the owners of zebu cattle to extend their seasonal transhumance and relocate their permanent settlements further south. The rate of interbreeding depends upon the breeding strategies and breed preferences of the farmers on the one hand and preferences of consumers on the other.

The primary objectives of this paper are to improve understanding of cattle farmers' breeding practices and breed preferences and determine if buyers have systematic preferences for specific breeds of cattle for specific purposes and whether they pay significantly different prices for different breeds consistent with their preferences. Ex ante assessment of farmers' breeding strategies and breed preferences and market values of different breeds can assist breed conservation and improvement efforts in several ways. First, it can help to assess current stocks of different breeds held by farmers, the geographic distribution of these stocks, and the likely future trends in these stocks. Interbreeding is more likely among animals raised in close proximity and when different breeds are raised in the same herd. Second, farmers' knowledge about specific attributes of different breeds under village conditions can help to focus scientific research on particular traits and identify needs for further farmer education through extension programmes. Third, it can help to determine the incentives that may need to be put in place for farmers to be involved in the conservation of threatened or endangered breeds that may not be supported by market forces. Fourth, information about farmers' breeding practices and breed preferences can help to identify the likely market for existing or improved breeds, as market information reveals buyer preferences for different breeds and attributes can be useful in the design of breed improvement schemes. 
In section 2 , the study area, data sources and analytical methods are described. In section 3, results are presented and discussed. Implications of the findings and conclusions are presented at the end.

\section{Data Source and Methodology}

\section{The study area}

In West and Central Africa, in the mid-1970s about 7 million Bos taurus cattle, including the 4.8 million N'Dama and the 2.2 million West African shorthorns, were most numerous in the more humid southern region, the trypanosusceptible Bos indicus breeds were most numerous in the drier northern region covering the Sahel, and most of the three million cross-breed populations were found in the boundary area between the two regions (ILCA/FAO/UNEP, 1979). The present study focused on a boundary area because interbreeding and genetic introgression is most likely in those areas and farmers in those areas are more likely to have information about the advantages and disadvantages of different breeds and the option of bringing different breeds into their herds. The particular boundary area chosen for this study is in the derived savannah ecozone - a transition zone between humid and sub humid zones of Oyo State, southwest Nigeria, where most of the cattle in southern Nigeria are located. Cattle breeds commonly found in southern Nigeria are: Muturu -- a trypanotolerant Bos taurus breed; White Fulani -- a trypanosusceptible Bos indicus breed; Keteku -- a stabilized cross between Muturu and White Fulani; and N'Dama -- a trypanotolerant Bos Taurus breed introduced into southern Nigeria through breed improvement programmes undertaken since the early 1970 s.

As of 1959 there were about 65,000 cattle in southern Nigeria, most of which were Muturu and Keteku. Since that time the number of cattle in southern Nigeria has increased rapidly as 
Fulbe pastoralists have moved large numbers of White Fulani cattle into the region. The cattle population increased to 100,000 in $1974 / 75$, to 140,000 in 1984 and to 234,000 in 1990 (RIM, 1992; Blench, 1994). At the same time the number of trypanotolerant cattle in the region, particularly Muturu and Keteku, have decreased. The number of Muturu in all of Nigeria has decreased from about 200,000 in 1938 to between $60,000-115,000$ in recent times (Hoste et al., 1992; Akinwumi and Ikpi, 1985; RIM, 1992).

Between 1980 and 1983, 5,000 N'Dama were imported from The Gambia to Nigeria as breeding stock. These were multiplied and disseminated from five government ranches in southern Nigeria. The total number of N'Dama in the country increased from 14,800 in 1975 to 24,800 in 1984 (ILCA/FAO/UNEP, 1979; Hoste et al., 1992). Although N'Dama are raised as multi-purpose animals in The Gambia, early adopters of the N'Dama in southern Nigeria raised them primarily for beef (Jabbar et al., 1995).

\section{Household sample and data}

A survey of cattle-holding households in the derived savanna ecozone of Oyo state was conducted between January and June 1994. Oyo state is divided into four administrative zones for agricultural extension purposes - Ibadan, Oyo, Ogbomosho and Shaki. Of these, Ibadan, which falls primarily in the forest zone, has a small number of Muturu cattle, but very few cattle of any other breed. The study therefore focused on the other three zones where a combination of breeds was known to be raised. Each zone is divided for administrative purposes into a number of block each containing 50-80 villages and 5,000-10,000 households. Based on information provided by the Ministry of Agriculture, from previous surveys and key informants, two blocks were selected from each of the three zones to represent the different agro climatic situations within the derived savannah ecozone of Oyo state. 
In the 6 sample blocks there were 377 villages and 41,321 households of which 292 (less than $1 \%$ ) were described as settled cattle farmers, i.e. farmers engaged in both livestock and crop production with a semi-permanent or permanent dwelling. All other households were principally crop farmers with some small ruminants but no cattle. Of the 292 households, 66 had cattle when they settled, but for a variety of reasons, had no cattle at the time of the survey. Individual interviews were conducted with the 226 households who held cattle at the time of the survey. Among them 210 belong to the Fulbe ethnic group who migrated from the north and 16 belong to the local Yoruba ethnic group.

Data were collected on settlement, breed and sex composition of cattle herds, and sources of cattle currently in the herd. Respondents were also asked open-ended questions about the main advantages and disadvantages of 5 breeds with which they might be familiar - White Fulani, Keteku, Muturu, N'Dama and crosses of White Fulani and N'Dama. Respondents were asked to rate, using a matrix rating approach, the 5 breeds according to a set of criteria that had emerged as most important from previous studies (e.g. Mohammed, 1990; Jabbar et al.,1995) and through key informant interviews with cattle farmers. The criteria were: milk yield, disease resistance, size of animal, ease of handling, market value, marketability (ease of finding buyers), ability to graze diverse species of grasses, need for moving long distances for grazing, and overall desirability. An animal with ability to graze diverse grasses would have less need for moving long distances for grazing but, to avoid disease infested areas, particularly that of trypanososmosis, animals may have to be moved long distances. The meaning of each row, column and cell in the matrix was explained to each respondent during the household interview. Each breed could be rated between 1 (poorest or lowest or least preferred) and 10 (best or highest or most preferred) for each criterion, so the respondent was asked to consider the first criteria and put between one and 10 bean seeds in the cell corresponding to each breed. The respondent was then asked to consider the remaining 8 
criteria in the same way. Of the 226 interviews that were conducted with sedentary cattle farmers, 204 (90 percent) produced complete data regarding breeding practices and breed preferences.

\section{Logit analysis of breed preference rating}

Preference rating is a response variable that can be considered as measured on an ordinal scale. The ordering shows the strength of preference for an item. The LOGISTIC procedure in SAS (SAS, 1995, 1999) can be used to fit a model with an ordinal response variable. This procedure fits a parallel lines regression model that is based on the cumulative distribution probabilities of the response categories.

In this study, the response has 10 possible outcomes: $1=$ strongly dislike, $\ldots, 10=$ strongly like.

So we define:

$\mathrm{P}_{\mathrm{i}}=\operatorname{prob}(\mathrm{Y}=1 \mid \mathrm{X})$, for $\mathrm{i}=1, \ldots, 10$

where $\mathrm{Y}$ is the response variable and $\mathrm{X}$ is a continuous predictor variable.

PROC LOGISTIC in SAS fits the following model:

$\operatorname{logit}\left(\mathrm{p}_{1}\right)=\log \left(\mathrm{p}_{1} /\left(1-\mathrm{p}_{1}\right)\right)=\alpha_{1}+\beta * \mathrm{X}$

$\operatorname{logit}\left(\mathrm{p}_{1}+\mathrm{p}_{2}\right)=\log \left(\left(\mathrm{p}_{1}+\mathrm{p}_{2}\right) /\left(1-\mathrm{p}_{1}-\mathrm{p}_{2}\right)\right)=\alpha_{2}+\beta * \mathrm{X}$ 
PROC LOGISTIC models the cumulative probabilities assuming a common slope parameter associated with the predictor variable. The model is called the proportional-odds model, because the ratio of the odds of the event $\mathrm{Y}$ inferior or equal to $\mathrm{j}$ is independent of the category, $\mathrm{j}$. This means that the odds ratio is constant for all categories.

In this analysis, the response levels are sorted in ascending order. The score chi-square is used to test the appropriateness of the proportional odds model. High p-value suggest adequacy of the model in fitting the data.

\section{Market data}

A rapid appraisal of cattle markets in southwest Nigeria was undertaken to characterize patterns of trade and breeds of animals transacted at each market. The Shaki market, located in the northwest of Oyo state, about 10 kilometres from the border between Nigeria and the Republic of Benin, was chosen for indepth study since the greatest variety of breeds were exchanged there. Data were collected for 2,688 cattle transactions conducted on 49 market days between November 1993 and June 1994. Data were collected more frequently when more animals were exchanged such as before festivals. All data were collected on Mondays, Wednesdays and Fridays. Five breeds of cattle were transacted during those 49 market days: Muturu, Keteku, N'Dama, White Fulani and Sokoto Gudali. The first three are trypanotolerant taurine breeds while the other two are trypanosuscptible zebu breeds. The rapid appraisal indicated that relatively few trypanotolerant cattle were exchanged compared to the trypanosuceptible breeds. In order to ensure adequate samples of all breeds, data were collected for all transactions involving N'Dama, Keteku and Muturu and a random sample of transactions involving White Fulani and Sokoto Gudali.

For each transaction, data were collected on price (Nigerian Naira per head) and various 
factors hypothesized to affect price: attributes of the animal, attributes of the seller and the buyer. Since animals are not weighed at the Shaki market, a Bovine Weighing Tape (manufactured by WASCO, Fort Atkinson, Wisconsin, USA) was used to measure height at the withers, length and girth circumference following the procedure described by Buvanendran et al. (1980). The tape gives an estimated weight of the animal corresponding to its girth circumference. Also weight was estimated by using the following formula: live weight $=\left(\right.$ length $\mathrm{x}$ girth $\left.{ }^{2}\right) / 300$ (Payne, 1990). The two weight estimates were found to be highly correlated $(r=0.97)$.

\section{Implicit price analysis}

An implicit or hedonic price function was estimated to relate the price per animal to its various attributes and characteristics. The maintained hypothesis of implicit price analysis is that products have attributes that confer utility and that the values of those attributes contribute to the price of the product. The observed product price is therefore a composite of the implicit prices of the product's attributes (Rosen, 1974; Lucas, 1975). In this analysis the focus was on the importance of breed relative to other attributes likely to affect the price of cattle. The hypothesis that was tested was as follows: everything else equal, there were no differences in price per animal due solely to breed.

In a competitive market an implicit price will be a function of the product attributes alone, and not of individual consumer or supplier attributes (Rosen, 1974; Ockowski, 1994). This implies that only products are differentiated, while their markets, buyers and sellers are not. However, most empirical studies found that price was also related to attributes of the buyers and sellers, implying some non-competitiveness in the market (e.g. Brorsen et al., 1984; Francis, 1990; Andargachew and Brokken, 1993; Parker, 1993; Parker and Zilberman, 1993; Williams et al., 1993; Oczkowski, 1994; Rodriguez et al., 1995). 
The general form of the implicit price function may be written as $\mathbf{P}=\mathbf{F}(\mathbf{Q}, \mathbf{C})+\mathbf{e}$

where $\mathrm{P}$ is the observed price of the product, $\mathbf{Q}$ is a set of qualitative (discrete) variables or factors each with more than one category, $\mathbf{C}$ is a set of quantitative variables (covariates), and e is an error term. Interaction variables may also be incorporated. The partial derivative of the estimated function with respect to a quantitative variable is the implicit marginal value of the attribute. Qualitative attributes are represented by dummy variables so the estimated parameters measure the impact of the presence or absence of the attribute. Therefore, the predicted price cannot be directly obtained from the partial derivatives, and hence additional manipulation would be required (Gujarati, 1988).

The SPSS Analysis of Covariance procedure (Norusis, 1993) was used to estimate the model parameters. Bonferroni confidence intervals were used in the hypothesis tests in order to reduce the likelihood of false rejection of null hypotheses. The advantage of this procedure compared to linear regression is that the results can be interpreted more directly and easily to compare differences between categories of a factor, as the estimated parameters indicate both the direction and absolute value of the differences from a base category. The factors and covariates used in the analysis are discussed later.

\section{Results and Discussion}

\section{Farmers' present and past breeding practices}

Among the 204 sample herds, 69\% contained only White Fulani, 24\% contained White Fulani and Keteku, 4\% contained mixtures including White Fulani, Keteku and N'Dama, and 3\% contained only Keteku. None of the herds contained Muturu. The 55 households that were caretakers of animals had been settled in their current location longer than other households (average of 40 years compared to 27 years) and were less likely to hold pure White Fulani herds (47\% compared to $77 \%$ ). Herd size and composition were fairly similar 
among the groups.

Table 1 shows how the breed composition of the farmers' cattle holdings changed over time. Overall, there was a large shift away from the indigenous Bos taurus breeds, Muturu and Keteku, to White Fulani. Before the survey, 55\% of the 204 households reared Muturu or Keteku, at the time of the survey $31 \%$ reared Keteku and none reared Muturu. While $44 \%$ of the households that had only White Fulani in the past had some Keteku at the time of the survey, $63 \%$ of the households that had only Muturu or Keteku in the past had only White Fulani at the time of the survey. Of the 113 farmers who gave reasons for giving up Muturu and/or Keteku, $75 \%$ mentioned poor market value, $66 \%$ mentioned low milk yield, 43\% mentioned small size, and $27 \%$ mentioned wild temperament or difficulty in management or handling. Of the 43 farmers who gave reasons for adding trypanotolerant breeds to their herds, $51 \%$ mentioned disease resistance, $26 \%$ mentioned ability to graze a variety of grasses therefore less need for mobility, $14 \%$ mentioned better quality of milk, and $12 \%$ mentioned shorter calving interval.

Data on sources of cattle in the respondents' herds at the time of the survey are presented in Table 2. These data suggest that care-taking arrangements and interbreeding are the main ways that farmers exercise breed choice in their herds. Overall, $80 \%$ of the cattle held by the respondents were inherited or born to animals that were inherited, $14 \%$ originated through care-taking arrangements, and just 5\% were purchased. Inheritance was the most important source for all breeds of cattle; care-taking was a much more important source for Keteku than for White Fulani.

\section{Breed preference rating results}

Table 3 shows the results of fitting the preference rating data to a logistic regression model. 
The model is parameterized so that the Muturu, used as a reference breed, is assigned a parameter estimate of zero. All comparisons are made with respect to this breed. Since the strong dislike or least preferred $(\mathrm{Y}=1)$ end of the rating scale is associated with lower ordered values in the response profile distribution, the probability of disliking the breeds is modeled. The Chi-Square score test for testing the proportional odds assumption for milk yield rating is not significant with respect to a chi-squared distribution with 32 degrees of freedom $(p=$ .4339). The proportional odds model assumption is therefore valid for milk yield rating. For other criteria, the p-values are very small because the probability distributions of ratings are more even rather than skewed as in the case of milk yield rating. The relative magnitudes of the parameter estimates with respect to each criterion imply the preference ordering as well as the distances between the breeds. Results in Table 3 shows that all the parameters are highly significant at $\mathrm{p}$-value $=0.05$, except in four cases where the outcome was not significant (ns in the table).

The results indicate that White Fulani is the most preferred breed and Keteku the second most preferred breed in terms of milk yield, size, ease of handling, market value, marketability, mobility needs while White Fulani is the least preferred breed and Keteku is second least preferred breed in terms of disease resistance and gazing diversity. N'Dama is the most preferred breed in terms of disease resistance and grazing diversity and the least or second least preferred breed in terms of milk yield, size, ease of handling, market value, marketability and mobility. Muturu is the second most preferred breed in terms of disease resistance and grazing diversity but least or second least preferred breed in terms of milk yield, size, ease of handling, market value, marketability and need for mobility. The White Fulani x N'Dama crosses lie somewhere in the middle. 
The distances between the breeds in relation to a specific criterion can further qualify these orders of preferences. For example, White Fulani is the most preferred breed in terms of milk yield and its distance from the second best breed, Keteku, is very large. Also White Fulani is the least preferred breed in terms of disease resistance and its distance from the second least preferred breed, Keteku, is also very large. On the other hand, N'Dama is the most preferred breed in terms of disease resistance and its distance from the next best breed, Muturu, is not statistically significant. In the case of marketability, there is an order of preference but the distances between the breeds are less pronounced compared to other criteria. Based on all the criteria, the order of preference is as follows: White Fulani, Keteku, White Fulani x N'Dama, Muturu, and N'Dama.

\section{Results of market and price analysis}

There are significant differences between breeds purchased by different buyer categories. Traders purchased $62 \%$ of the Muturu and $56 \%$ of the Keteku. Sixty-six percent of all cattle traded were males, $29 \%$ were cows and 5\% were heifers. Sixty-nine per cent of the traded animals were sold by traders and $31 \%$ were sold by farmers. Of the traded animals, $51 \%$ were purchased by traders for resale mainly in Eastern Nigeria, Lagos, Ibadan and in the local market, $23 \%$ were purchased by butchers and catering restaurants; $14 \%$ were purchased by consumers for various ceremonies and festivals, and $11 \%$ by farmers for rearing. Traders mostly purchased males (86\%), while butchers mostly purchased females $(77 \%)$. Farmer purchases included $7 \%$ cows, $32 \%$ heifers, $23 \%$ young males and $38 \%$ bulls, all of these mainly for rearing.

In the absence of weighing facilities in the market, because of their regular engagements in the market, traders and butchers have developed more experience and skill than other types of 
buyers and sellers in evaluating the product quality attributes of each animal, the true value and the value a buyer or seller may put on it. This skill and knowledge primarily influence the margin they are able to derive from each transaction.

In the overall implicit price model run with the entire sample of traded animals, buyer type or purpose of buying was used as a factor along with other factors and covariates. In order to test whether differences in breed preferences for specific purposes were also reflected in price differences, interaction terms between purpose of buying and breed and type of animal were introduced. But because not all breeds were purchased for all purposes, or in some cases very few animals were purchased for a specific purpose, several cells in the data matrix were empty. In such cases, the model estimates the coefficients of the interaction terms assuming those empty cells as null or zero values but the hypothesis being tested in this way was not the hypothesis of interest in this study (see Norusis, 1993, for an explanation of the implications of estimating parameters assuming zero or empty cells). Therefore, rather than introducing interaction terms in the overall model, separate models were fitted to animals purchased for specific purposes, using relevant factors and categories.

Table 4 reports the results of the two best fit implicit price models, based on overall explanatory power, that were fitted to the entire sample. The difference between the two models is the exclusion of weight and weight square as covariates in model 1 , so that the parameters of model 1 are not adjusted for differences in weight (a proxy for size) of the animals. The matrix rating from farm survey revealed that size is an important inherent characteristic of the various breeds - White Fulani and Gudali are larger compared to the other breeds. Therefore any significant price difference between breeds unadjusted for size may indicate that breed per se is valued by buyers (personal communication, Professor Robert Mendelshon, Yale University, 2000). The results, however, indicate that holding everything else equal, except size, there is no significant price difference between White Fulani and 
Gudali, but the prices of all three trypanotolerant breeds are significantly lower than White Fulani and Gudali. When size is adjusted in model 2, no significant price difference exists between White Fulani, Gudali and N'Dama, but the prices of Keteku and Muturu are significantly lower, albeit with a much reduced magnitude. However, model 1 explains only $46 \%$ of total variation in prices compared to $72 \%$ in model 2 indicating that buyers consider both breed and size in valuing an animal. The significant negative effect of weight square in model 2 indicates that overall less premium is paid for heavier animals while the significant positive effect of condition score square indicates that higher premium is paid for animals in good condition.

Other significant results are that : (a) cows fetched significantly lower prices than males, while heifers fetched significantly higher prices than males; (b) traders paid significantly higher prices than either farmers or butchers/caterers/consumers (treatment of butchers, caterers and consumers as separate categories showed no significant difference between them hence they were combined); and (c) the highest prices were paid in December and lowest in January- March period.

Results of the purpose or buyer type specific models presented in Table 5 show that the explanatory power varies from $68 \%$ for animals purchased by farmers, to $79 \%$ for animals purchased by traders and $62 \%$ for animals purchased by butchers/caterers/consumers. Farmers did not pay significantly different prices for different breeds, but they paid significantly higher prices for cows and heifers compared to males, as they purchased animals mainly for rearing/breeding. Condition of animals did not significantly influence price paid by farmers, perhaps because if other desirable characteristics were present, the condition of the animal could be improved through rearing and appropriate management. Traders paid significantly lower prices for Muturu and Keteku compared to the other three breeds, also paid significantly 
lower prices for cows (these are generally culled old cows having poor meat quality, hence the lower price), paid premium prices for animals in good condition and less premium for larger animals. Butchers/caterers/consumers paid significantly lower prices for Keteku compared to the other breeds, also paid lower prices for cows, and paid higher prices for larger animals as well animals in good condition.

\section{Conclusions and Implications of Findings}

Farmers in the derived savannah zone of Oyo State make deliberate choices about breeds of cattle in their herds based on specific criteria. They acquire breeds of choice principally through inheritance and breeding within own herds as well as through purchase and caretaking of other farmers' cattle. About $75 \%$ of the respondents reported that the breed composition of their herd was different at the time of the survey than it was in the past. There is a strong trend away from the Bos taurus Muturu and Keteku toward the Bos indicus White Fulani. Keteku was developed by interbreeding in the past by farmers as a deliberate choice to combine the disease resistance of Muturu and the larger size and milk yield of White Fulani. However, the decreasing number of Keteku at present indicates that as Muturu have disappeared from farmers' herds, so too may the Keteku. Although farmers acknowledged some clear advantages of the Muturu and Keteku (disease resistance, ability to graze a variety of grasses), those advantages appear to be of relatively little importance compared to the many disadvantages of the Muturu and Keteku relative to the White Fulani. Moreover, where disease challenge particularly that of trypanosomosis is smaller, there is less incentive to choose Muturu and Keteku against White Fulani.

The movement away from Muturu in the derived savannah areas of Oyo State is consistent with the aggregate trend in southwestern Nigeria. The national livestock survey conducted in 
the early 1990s (RIM, 1992) found virtually no Muturu in Ogun State where not long ago many farmers held the breed (Grandin, 1980). The national livestock survey reported 11,623 Muturu among a total of 234,461 cattle in Oyo State (now Oyo and Osun states), but most of those Muturu were located in the forested areas.

The results of market price analysis show that there are some differences in prices that are solely due to breed, but that most variation in prices is due to size and condition of the animals. Generally, other things being equal, trypanotolerant breeds (Keteku, Muturu and N'Dama) commanded significantly lower prices compared to the larger trypanosuceptible breeds (White Fulani and Gudali). Although N'Dama prices generally appeared slightly higher than other breeds, in no case was the difference statistically significant. In an earlier analysis, girth and girth square rather than weight and weight square were used as covariates, and N'Dama prices in that case were found significantly higher than other breeds (See, Jabbar et al., 1998). However, purpose-specific equations run in this paper but not in the earlier case, show that overall, N'Dama has a slight edge, but not a significant one, in the market among all categories of buyers. But the total number of N'Dama in the sample is smaller in relation to the other breeds so this result should be treated with caution. However, this outcome is consistent with farm survey results, which show that farmers rated N'Dama low in terms of milk yield, ease of handling, market value and marketability. Though they rated N'Dama high in terms of disease resistance and grazing diversity. This partly explains why N'Dama population in the study area as well as in the rest of Nigeria did not expand as rapidly as would be expected after initial introduction by the government-funded project.

The strong trend among farmers against the trypanotolerant breeds especially Muturu implies that there is very little scope for conservation of the Muturu through continued farmer rearing in the derived savannah areas of southern Nigeria. If trends from the study area expand into the forested part of Oyo State, the population of 11,000 Muturu that is now reported could be 
lost in a few years through interbreeding or outright exclusion from herds. This would mean the loss of an important resource for Nigeria and all regions of the world where livestock are raised under the stresses of disease, heat and humidity. The ability to be productive under low to moderate levels of trypanosomosis makes these animals more attractive to farmers. Trypanosomosis remains a constraint in southern Nigeria $^{1}$ and especially as there is evidence from across Africa of resistance to the drugs available for prophylactic and curative treatment of trypanosomosis (Peregrine et al., 1994).

Research and development agencies should consider the possibility of selecting Muturu bulls with superior production characteristics and promoting them with farmers who now keep Muturu in the forest zone. Conservation efforts might be better directed at locations, such as southeast Nigeria, where the Muturu is better suited to the farming system and where there is a distinct market for Muturu.

Note

1 In 1987, in a sample of 1525 zebu cattle in 5 states of southwest Nigeria, a mean rate of trypanosome prevalence of $14.4 \%$ was found $-18 \%$ in the wet and $10.8 \%$ in the dry season (Ikede et al., 1987). A repeat survey in slightly wetter and more forested locations in 3 of the same 5 States showed prevalence rates of between $18.5 \%-21 \%$ in the wet season and $16 \%$ in the dry season (ILRI-Ibadan, unpublished data).

\section{References}

Akinwumi, J.A. and Ikpi, J.E., 1985. Trypanotolerant cattle production in southern Nigeria. Unpublished report. Ibadan, Nigeria: International Livestock Centre for Africa. 
Andargachew, K. and Brokken, R.F., 1993. Intra-annual sheep price patterns and factors underlying price variations in the central highlands of Ethiopia. Agric. Econ., 8:125138.

Blench, R., 1994. The expansion and adaptation of Fulbe pastoralism to subhumid and humid conditions in Nigeria. Cahiers d'Etudes Africaines. 34:197-212.

Brorsen, B. W., Grant, W. R., and Rister, M. E., 1984. A hedonic price model for rough rice bid/acceptance markets. American J. Agric. Econ., 66:156-163.

Buvanendran, V. W., Umoh, J.E., and Abubakar, B. Y., 1980. An evaluation of body size as related to weight of three west African breeds of cattle in Nigeria. J. Agric. Sc (Camb.), 95:219-224.

Cunningham, E.P., 1992. Animal genetic resources: the perspective for developing countries. In: Rege, J.E.O. and Lipner, M.E. (Editors), African Animal Genetic Resources: Their Characterization, Conservation and Utilisation. International Livestock Centre for Africa, Addis Ababa, Ethiopia; 7-10.

Francis, P., 1990. Small-ruminant marketing in southwest Nigeria. Agric. Econ., 4:193-208.

Grandin, B.E., 1980. Small Cows, Big Money: Wealth and Dwarf Cattle Production in southwestern Nigeria. Ph.D. Thesis. Stanford University, Stanford CA.

Gujarati, Damodor N., 1988. Basic Econometrics. $2^{\text {nd }}$ edition. McGraw Hill, New York, USA.

Hall, S.J.G. and Ruane, J., 1993. Livestock breeds and their conservation - global review. Con. Biol., 7(4): 815-825.

Hoste, C.H., Chalon, E., d'Ieteren, G., and Trail, J. C. M., 1992. Trypanotolernat Livestock in West and Central Africa. Vol. 3- A Decade's Results. Monograph 2. International 
Livestock Centre for Africa, Addis Ababa, Ethiopia.

d'Ieteren, G.D.M., 1994. Trypanotolerant livestock, a sustainable option for increasing livestock production in tsetse-affected areas. In: Rowlands, G.J. and Teale, A. J. (Editors), Towards Increased Use of Trypanotolerance: Current Research and Future Options. Proceedings of a Workshop organized by ILRAD and ILCA. ILRAD and ILCA, Nairobi, Kenya; 3-14.

Ikede, B. O., Reynolds, L., Ogunsanmi, A. O., Fawumi, M. K., Ekwuruke, J. O., and Taiwo, V., 1987. The epizootiology of bovine trypanosomiasis in the derived savanna zone of Nigeria: a preliminary report. Paper presented at the 19th meeting of the ISCTRC, Lome, Togo, March 30 - April 3.

ILCA/FAO/UNEP, 1979. Trypanotolerant Livestock in West and Central Africa, Vol. 1, General Study. Monograph No.2. International Livestock Centre for Africa, Addis Ababa, Ethiopia.

Jabbar, M. A., Reynolds, L., and Francis, P.A., 1995. Sedentarisation of cattle farmers in the derived savannah region of south-west Nigeria: results of a survey. Trop. Anim. Hlth. Prod., 27:55-64.

Jabbar, M. A., Swallow, B. M., d'Iteren, G. D. M. and Busari, A. A., 1998. Farmer preferences and market values of cattle breeds of West and Central Africa. J. Sustain. Agric., 12(2/3):21-47.

Lucas, Rober E.B., 1975. Hedonic price functions. Econ. Enquiry, 13:157-178.

Mohammed, T. A., 1990. A study of peri-urban cattle pastoralism in the derived savanna of Oyo State, southwest Nigeria. Unpublished report, ILCA Humid Zone Programme, Ibadan, Nigeria.

Murray, Max, Trail, J. C. M., and d'Ieteren, G. D. M., 1990. Trypanotolerance in cattle and 
prospects for the control of trypanosomiasis by selective breeding. OIE Sci. and Tech. Rev., 9:369-386.

Norusis, Marija J., 1993. SPSS for windows: Advanced statistics, Release 6. SPSS Inc., Chicago.

Oczkowski, E., 1994. A hedonic price function for Australian premium table wine. Aus. J. of Agric. Econ.,38: 93-110.

Parker, D.D., 1993. Retail price response to quality characteristics of fresh peaches by store type. Agribusiness., 9:205-215.

Parker, D. D. and Zilberman, D., 1993. Hedonic estimation of quality factors affecting the farm-retail margin. American J. Agric. Econ., 75:458-466.

Peregrine, A.S., 1994. Chemotherapy and delivery systems: Haemoparasites. Vet. Parasit.,54:223-248.

Payne, W. J. A., 1990. An introduction to animal husbandry in the tropics. $4^{\text {th }}$ edition. Longman, London, UK.

Rege, J. E. O., 1999. The state of African cattle genetic resources. I Classification framework and identification of threatened and extinct breeds. Animal Genetic Resources Infor. Bull., 25: 1-26.

RIM (Resource Inventory and Management), 1992. Nigerian livestock resources, Vol I-IV. RIM, Jersey, U.K.

Rodriguez, A., Ali, I., Afzal, M., Shah, N. A., and Mustafa, U., 1995. Price expectations of sheep and goats by producers and intermediaries in Quetta market, Pakistan. Agric. Econ.,12:79-90.

Rosen, S., 1974. Hedonic prices and implicit markets: Product differentiation in pure competition. J. Pol. Econ., 82:34-55.

SAS., 1995. Logistic Regression Examples Using the SAS System, Version 6, First Edition. 
Cary, NC: SAS Institute Inc. 163 pp.

SAS., 1999. SAS/STAT User's Guide, Version 8, Cary, NC: SAS Institute Inc. 3884 pp.

Williams, C.H., Rolf, J., and Longworth, J W., 1993. Does muscle matter? An economic valuation of live cattle characteristics. Rev. Marketing and Agric Econ., 61(2):169189. 
Table 1: Distribution of sample households according to past and present (January June 1994) breeds of cattle in the herds, southwest Nigeria

\begin{tabular}{|c|c|c|c|c|c|c|}
\hline \multirow[b]{2}{*}{ Past breeds } & \multicolumn{3}{|c|}{ Present breeds } & \multirow[b]{2}{*}{$\begin{array}{l}\text { WF + } \\
\text { Keteku + } \\
\text { N'Dama }\end{array}$} & \multirow[b]{2}{*}{$\begin{array}{l}\text { All herds } \\
\text { (n) }\end{array}$} & \multirow[b]{2}{*}{$\begin{array}{r}\text { All } \\
\text { herds } \\
(\%)\end{array}$} \\
\hline & $\begin{array}{l}\text { White } \\
\text { Fulani } \\
(\mathrm{WF})\end{array}$ & Keteku & $\begin{array}{l}\text { WF + } \\
\text { Keteku }\end{array}$ & & & \\
\hline White Fulani & 51 & 4 & 34 & 2 & 91 & 45 \\
\hline Keteku & 21 & - & - & 1 & 22 & 11 \\
\hline Muturu & 1 & - & 12 & 5 & 18 & 9 \\
\hline WF+Muturu & - & 3 & - & - & 3 & 1 \\
\hline Keteku+Muturu & 61 & - & 2 & 1 & 64 & 31 \\
\hline Mixtures $^{\mathrm{a}}$ & 6 & - & - & - & 6 & 3 \\
\hline All herds (n) & 140 & 7 & 48 & 9 & 204 & \\
\hline All herds (\%) & 69 & 3 & 24 & 4 & & 100 \\
\hline
\end{tabular}

${ }^{a}$ Mixtures of White Fulani, Keteku, N'Dama, White Fulani x N'Dama crosses.

Source: Farm survey 
Table 2: $\quad$ Sources of cattle by breeds in the sample herds, southwest Nigeria

\begin{tabular}{|c|c|c|c|c|}
\hline \multirow[t]{2}{*}{ Breeds in herd } & \multicolumn{4}{|c|}{$\%$ animals for each breed by source } \\
\hline & Inherited & Purchased & $\begin{array}{l}\text { Share of } \\
\text { caretaking }\end{array}$ & Caretaking \\
\hline White Fulani (WF) & 85.1 & 4.5 & 0.2 & 10.2 \\
\hline Keteku & 56.0 & 6.7 & - & 37.3 \\
\hline $\mathrm{WF}+\mathrm{Keteku}$ & 84.1 & 5.1 & 1.3 & 9.5 \\
\hline WF & 91.2 & 5.6 & 0.3 & 2.8 \\
\hline Keteku & 74.0 & 4.4 & 2.6 & 19.0 \\
\hline Mixtures $^{\mathrm{a}}$ & 19.1 & 5.1 & 6.4 & 69.4 \\
\hline WF & 56.9 & 18.5 & 3.1 & 21.5 \\
\hline Keteku & 15.1 & - & 7.5 & 77.4 \\
\hline $\begin{array}{l}\text { N'Dama+ } \\
\text { WFxN'Dama }\end{array}$ & - & - & 7.7 & 92.3 \\
\hline All herds & 80.9 & 4.8 & 0.8 & 13.5 \\
\hline
\end{tabular}

a. same as in Table 1.

Source: Farm survey 
Table 3. Maximun likelihood estimates of breeds rating ( Standard errors are in brackets).

\begin{tabular}{|c|c|c|c|c|c|c|c|c|c|}
\hline Parameter & Milk yield & $\begin{array}{l}\text { Disease } \\
\text { Resistance }\end{array}$ & Size & Handling & $\begin{array}{l}\text { Market } \\
\text { Value }\end{array}$ & $\begin{array}{l}\text { Market- } \\
\text { ability }\end{array}$ & $\begin{array}{l}\text { Grazing } \\
\text { diversity }\end{array}$ & $\begin{array}{l}\text { Mobility } \\
\text { Need }\end{array}$ & $\begin{array}{l}\text { Overall } \\
\text { Rating }\end{array}$ \\
\hline$\alpha_{1}$ & $\begin{array}{c}-1.8097 \\
(0.1722)\end{array}$ & $\begin{array}{l}-8.8707 \\
(0.3259)\end{array}$ & $\begin{array}{l}-0.5795 \\
(0.1404)\end{array}$ & $\begin{array}{l}-1.0006 \\
(0.1447)\end{array}$ & $\begin{array}{l}-0.7727 \\
(0.1417)\end{array}$ & $\begin{array}{l}-1.6008 \\
(0.1565)\end{array}$ & $\begin{array}{l}-10.8787 \\
(0.4025)\end{array}$ & $\begin{array}{l}-4.513 \\
(0.1355)\end{array}$ & $\begin{array}{l}-1.7217 \\
(0.1548)\end{array}$ \\
\hline$\alpha_{2}$ & $\begin{array}{l}0.1414 \mathrm{~ns} \\
(0.133)\end{array}$ & $\begin{array}{l}-7.7246 \\
(0.3033)\end{array}$ & $\begin{array}{l}1.2528 \\
(0.1556)\end{array}$ & $\begin{array}{l}0.6841 \\
\quad(0.1384)\end{array}$ & $\begin{array}{l}1.1205 \\
(0.1487)\end{array}$ & $\begin{array}{r}0.0111 \\
(0.1314)\end{array}$ & $\begin{array}{r}-8.7647 \\
(0.3602)\end{array}$ & $\begin{array}{l}1.1938 \\
(0.1457)\end{array}$ & $\begin{array}{l}-0.3882 \\
(0.1310)\end{array}$ \\
\hline$\alpha_{3}$ & $\begin{array}{l}1.3065 \\
(0.1453)\end{array}$ & $\begin{array}{l}-6.4471 \\
(0.2702)\end{array}$ & $\begin{array}{l}2.4983 \\
(0.1820)\end{array}$ & $\begin{array}{l}1.7628 \\
(0.1622)\end{array}$ & $\begin{array}{r}2.4815 \\
(0.1768)\end{array}$ & $\begin{array}{c}1.0904 \\
(0.1405)\end{array}$ & $\begin{array}{l}-7.0967 \\
(0.3086)\end{array}$ & $\begin{array}{c}-2.4503 \\
(0.1716)\end{array}$ & $\begin{array}{l}0.5977 \\
(0.1323)\end{array}$ \\
\hline$\alpha_{4}$ & $\begin{array}{l}2.6285 \\
(0.1697)\end{array}$ & $\begin{array}{l}-4.8602 \\
(0.2153)\end{array}$ & $\begin{array}{l}3.7447 \\
(0.2053)\end{array}$ & $\begin{array}{l}3.1676 \\
(0.1955)\end{array}$ & $\begin{array}{c}3.7574 \\
(0.2036)\end{array}$ & $\begin{array}{c}2.3484 \\
(0.1668)\end{array}$ & $\begin{array}{l}-5.4616 \\
(0.2352)\end{array}$ & $\begin{array}{l}3.5256 \\
(0.1900)\end{array}$ & $\begin{array}{l}1.7004 \\
(0.1473)\end{array}$ \\
\hline$\alpha_{5}$ & $\begin{array}{l}3.8204 \\
(0.1894)\end{array}$ & $\begin{array}{c}-3.5417 \\
(0.1924)\end{array}$ & $\begin{array}{l}5.0715 \\
(0.2255)\end{array}$ & $\begin{array}{l}4.3938 \\
(0.2220)\end{array}$ & $\begin{array}{c}4.8703 \\
(0.2251)\end{array}$ & $\begin{array}{c}3.6387 \\
(0.2012)\end{array}$ & $\begin{array}{l}-4.0184 \\
(0.2085)\end{array}$ & $\begin{array}{c}4.6847 \\
(0.2134)\end{array}$ & $\begin{array}{c}2.5580 \\
(0.1615)\end{array}$ \\
\hline$\alpha_{6}$ & $\begin{array}{l}4.9437 \\
(0.2140)\end{array}$ & $\begin{array}{c}-2.2779 \\
(0.1700)\end{array}$ & $\begin{array}{c}6.0028 \\
(0.2406)\end{array}$ & $\begin{array}{l}5.4624 \\
(0.2450)\end{array}$ & $\begin{array}{c}5.8816 \\
(0.2446)\end{array}$ & $\begin{array}{r}4.6930 \\
(0.2293)\end{array}$ & $\begin{array}{c}-2.7082 \\
(0.1870)\end{array}$ & $\begin{array}{c}5.8832 \\
(0.2619)\end{array}$ & $\begin{array}{l}3.2825 \\
(0.1748)\end{array}$ \\
\hline$\alpha_{7}$ & $\begin{array}{l}6.0502 \\
(0.2592)\end{array}$ & $\begin{array}{l}-1.1820 \\
(0.1443)\end{array}$ & $\begin{array}{l}7.0341 \\
(0.2668)\end{array}$ & $\begin{array}{l}6.0539 \\
(0.2608)\end{array}$ & $\begin{array}{l}6.7877 \\
(0.2643)\end{array}$ & $\begin{array}{l}5.4594 \\
(0.2447)\end{array}$ & $\begin{array}{l}-1.7685 \\
(0.1629)\end{array}$ & $\begin{array}{c}6.4511 \\
(0.2982)\end{array}$ & $\begin{array}{l}3.8815 \\
(0.1873)\end{array}$ \\
\hline$\alpha_{8}$ & $\begin{array}{l}7.5584 \\
(0.3334)\end{array}$ & $\begin{array}{c}0.1754 \mathrm{~ns} \\
(0.1321)\end{array}$ & $\begin{array}{l}8.9002 \\
(0.3561)\end{array}$ & $\begin{array}{l}7.4841 \\
(0.3133)\end{array}$ & $\begin{array}{l}8.2293 \\
(0.3140)\end{array}$ & $\begin{array}{l}6.6025 \\
(0.2663)\end{array}$ & $\begin{array}{l}-0.4131 \\
(0.1345)\end{array}$ & $\begin{array}{l}7.7510 \\
(0.3891)\end{array}$ & $\begin{array}{l}4.8568 \\
(0.2105)\end{array}$ \\
\hline$\alpha_{9}$ & $\begin{array}{c}8.1187 \\
(0.3473)\end{array}$ & $\begin{array}{l}1.0739 \\
(0.1423)\end{array}$ & $\begin{array}{c}9.4867 \\
(0.3711)\end{array}$ & $\begin{array}{c}8.1019 \\
(0.329)\end{array}$ & $\begin{array}{c}8.8580 \\
(0.3320)\end{array}$ & $\begin{array}{r}7.3296 \\
(0.2798)\end{array}$ & $\begin{array}{c}0.4674 \\
(0.1352)\end{array}$ & $\begin{array}{c}8.2986 \\
(0.4094)\end{array}$ & $\begin{array}{c}5.2024 \\
(0.2184)\end{array}$ \\
\hline White Fulani & $\begin{array}{l}-8.8304 \\
(0.3641)\end{array}$ & $\begin{array}{l}7.8907 \\
(0.3148)\end{array}$ & $\begin{array}{l}-10.3379 \\
(0.3903)\end{array}$ & $\begin{array}{l}-8.8464 \\
(0.3495)\end{array}$ & $\begin{array}{l}-9.9122 \\
(0.3596)\end{array}$ & $\begin{array}{l}-7.7889 \\
(0.3027)\end{array}$ & $\begin{array}{c}9.1482 \\
(0.3710)\end{array}$ & $\begin{array}{l}-9.7868 \\
(0.4387)\end{array}$ & $\begin{array}{l}-5.3352 \\
(0.2408)\end{array}$ \\
\hline Keteku & $\begin{array}{l}-3.6576 \\
(0.2149)\end{array}$ & $\begin{array}{l}3.1970 \\
(0.2130)\end{array}$ & $\begin{array}{l}-5.3877 \\
(0.2524)\end{array}$ & $\begin{array}{l}-4.6604 \\
(0.2466)\end{array}$ & $\begin{array}{r}-5.7037 \\
(0.2594)\end{array}$ & $\begin{array}{l}-5.2407 \\
(0.2560)\end{array}$ & $\begin{array}{l}3.5490 \\
(0.2247)\end{array}$ & $\begin{array}{l}-3.6064 \\
(0.2181)\end{array}$ & $\begin{array}{l}-2.6979 \\
(0.1962)\end{array}$ \\
\hline Ndama & $\begin{array}{l}-0.6345 \\
(0.1799)\end{array}$ & $\begin{array}{l}-0.3454 \mathrm{~ns} \\
(0.1776)\end{array}$ & $\begin{array}{l}-2.0488 \\
(0.2021)\end{array}$ & $\begin{array}{l}1.4048 \\
(0.1951)\end{array}$ & $\begin{array}{l}-1.3464 \\
(0.1905)\end{array}$ & $\begin{array}{l}0.00729 \\
(0.1771)\end{array}$ & $\begin{array}{c}-0.5056 \\
(0.1832)\end{array}$ & $\begin{array}{l}0.2078 \mathrm{~ns} \\
(0.1836)\end{array}$ & $\begin{array}{l}0.5377 \\
(0.1770)\end{array}$ \\
\hline WfulaniXNdama & $\begin{array}{l}-2.7930 \\
(0.2028)\end{array}$ & $\begin{array}{l}3.6310 \\
(0.2197)\end{array}$ & $\begin{array}{l}-4.1243 \\
(0.2345)\end{array}$ & $\begin{array}{l}-2.4506 \\
(0.2051)\end{array}$ & $\begin{array}{l}-3.5252 \\
(0.2229)\end{array}$ & $\begin{array}{l}-2.1557 \\
(0.1947)\end{array}$ & $\begin{array}{l}3.9783 \\
(0.2317)\end{array}$ & $\begin{array}{l}-2.6941 \\
(0.2047)\end{array}$ & $\begin{array}{l}-1.6098 \\
(0.1838)\end{array}$ \\
\hline $\begin{array}{l}\text { Muturu } \\
\text { Chi-Square test }\end{array}$ & 0.000 & 0.000 & 0.000 & 0.000 & 0.000 & 0.000 & 0.000 & 0.000 & 0.000 \\
\hline Prob. With $32 \mathrm{df}$ & ns & $<.0001$ & $<.0001$ & $<.0001$ & $<.05$ & $<.0001$ & $<.0001$ & $<.0001$ & $<.0001$ \\
\hline
\end{tabular}


Table 4. Determinants of cattle prices per head, Shaki market, Southwest Nigeria

\begin{tabular}{|c|c|c|}
\hline $\begin{array}{l}\text { Factors and } \\
\text { covariates }\end{array}$ & $\begin{array}{l}\text { All samples: Model } 1 \\
\beta \text { (st error) }\end{array}$ & $\begin{array}{l}\text { All samples: Model } 2 \\
\beta \text { (st error) }\end{array}$ \\
\hline Intercept & $1662.33(603.01)$ & $391.09(447.13)$ \\
\hline \multicolumn{3}{|l|}{ Breed } \\
\hline White Fulani & 0.0 & 0.0 \\
\hline Gudali & $138.68(124.89)$ & $-53.08(90.71)$ \\
\hline Keteku & $-1645.14 *(90.86)$ & $-508.06 *(70.81)$ \\
\hline Muturu & $-1912.50 *(117.51)$ & $-404.41 *(92.35)$ \\
\hline N'Dama & $-869.01 *(386.57)$ & $352.17(281.46)$ \\
\hline \multicolumn{3}{|l|}{ Type of animal } \\
\hline Male & 0.0 & 0.0 \\
\hline Cow & $-21.85(96.37)$ & $-1379.31 *(79.87)$ \\
\hline Heifer & $246.10(186.93)$ & $412.00(135.48)$ \\
\hline \multicolumn{3}{|l|}{ Trading month } \\
\hline November93 & 0.0 & 0.0 \\
\hline December & $779.28 *(98.08)$ & $887.05 *(71.10)$ \\
\hline Jan-Febru94 & $131.92(115.25)$ & $152.25(83.51)$ \\
\hline March-April & $-345.75)^{*}(141.39)$ & $271.24 *(103.33)$ \\
\hline \multicolumn{3}{|l|}{ May } \\
\hline \multicolumn{3}{|l|}{ June } \\
\hline \multicolumn{3}{|l|}{ Buyer type } \\
\hline Farmer & 0.0 & 0.0 \\
\hline Trader & $1392.22 *(133.94)$ & $416.59 *(100.43)$ \\
\hline $\begin{array}{l}\text { Butcher/caterer/ } \\
\text { consumer }\end{array}$ & $876.23 *(143.22)$ & $56.17(106.01)$ \\
\hline \multicolumn{3}{|l|}{ Covariates } \\
\hline Condition score & $-34.75(153.70)$ & 41.41(111.99) \\
\hline Condition score $^{2}$ & $105.98 * * *(14.48)$ & $46.67 * * *(10.61)$ \\
\hline Weight & & $20.92 * * *(1.26)$ \\
\hline Weight $^{2}$ & & $-0.006 * * *(0.002)$ \\
\hline$\overline{\mathrm{R}^{2}}$ & 0.47 & 0.72 \\
\hline Adj $R^{2}$ & 0.46 & 0.72 \\
\hline $\mathrm{N}$ & 2688 & 2688 \\
\hline
\end{tabular}

For coefficients of covariates $* * *, * *$ and $*$ indicate $\mathrm{t}$ significant respectively at $\mathrm{p}<1 \%, 5 \%$ and $10 \%$. For coefficient of the factor categories, * indicate the coefficient is significantly different from 0 i.e. the base category within the factor. Here significance is based on 0.95 Bonferroni confidence interval because when joint confidence intervals are constructed, $\mathrm{t}$ values are inadequate to determine whether differences are significant (Norusis, 1993). 
Table 5. Determinants of cattle prices per head by type of buyer, Shaki market, Southwest Nigeria

\begin{tabular}{|c|c|c|c|}
\hline $\begin{array}{c}\text { Factors and } \\
\text { covariates }\end{array}$ & $\begin{array}{l}\text { Farmer buyers } \\
\beta \text { (st error) }\end{array}$ & $\begin{array}{l}\text { Trader buyers } \\
\beta \text { (st error) }\end{array}$ & $\begin{array}{l}\text { Butcher/caterer/ } \\
\text { consumer buyers } \\
\beta \text { (st error) }\end{array}$ \\
\hline Intercept & $3.65(1107.98)$ & $593.74(873.57)$ & $1524.40 * *(680.70)$ \\
\hline \multicolumn{4}{|l|}{ Breed } \\
\hline White Fulani & 0.0 & 0.0 & 0.0 \\
\hline Gudali & $-283.40(192.70)$ & $35.18(128.16)$ & $-78.80(137.03)$ \\
\hline Keteku & $-191.26(152.74)$ & $-567.62 *(100.79)$ & $-395.81 *(107.96)$ \\
\hline Muturu & $-251.14(191.83)$ & $-465.21 *(123.64)$ & $-149.77(161.19)$ \\
\hline N'Dama & $595.05(356.07)$ & $747.95(621.65)$ & $263.64(393.32)$ \\
\hline \multicolumn{4}{|l|}{ Type of animal } \\
\hline Male & 0.0 & 0.0 & 0.0 \\
\hline Cow & $624.39 *(245.56)$ & $-2044.56 *(118.29)$ & $-714.46 *(117.56)$ \\
\hline Heifer & $1143.51 *(119.42)$ & $386.90(362.15)$ & $-335.32(284.69)$ \\
\hline \multicolumn{4}{|l|}{ Trading month } \\
\hline November93 & 0.0 & 0.0 & 0.0 \\
\hline December & $771.10 *(137.70)$ & $1248.33 *(94.14)$ & $105.57(124.48)$ \\
\hline Jan-Febru94 & $758.38 *(164.87)$ & $236.97 *(112.47)$ & $-551.43 *(143.02)$ \\
\hline March-April & $472.818(200.78)$ & $709.47 *(142.41)$ & $-607.09 *(168.54)$ \\
\hline \multicolumn{4}{|l|}{ Covariates } \\
\hline Condition score & $656.08(400.16)$ & $79.94(160.29)$ & $-452.79 * *(185.49)$ \\
\hline Condition score $^{2}$ & $-27.74(37.98)$ & $31.55^{* *}(13.81)$ & $105.94 * * *(19.37)$ \\
\hline Weight & $23.71 * * *(5.52)$ & $28.17 * * *(1.62)$ & $11.29 * * *(2.26)$ \\
\hline Weight $^{2}$ & $-0.035 * *(0.017)$ & $-0.01 * * *(0.003)$ & $0.001(0.004)$ \\
\hline$\overline{\mathrm{R}^{2}}$ & 0.68 & 0.79 & 0.62 \\
\hline${\operatorname{Adj~} R^{2}}^{2}$ & 0.66 & 0.79 & 0.62 \\
\hline $\mathrm{N}$ & 270 & 1137 & 856 \\
\hline
\end{tabular}

For coefficients of covariates $* * *, * *$ and $*$ indicate $\mathrm{t}$ significant respectively at $\mathrm{p}<1 \%, 5 \%$ and $10 \%$. For coefficient of the factor categories, * indicate the coefficient is significantly different from 0 i.e. the base category within the factor. Here significance is based on 0.95 Bonferroni confidence interval because when joint confidence intervals are constructed, $\mathrm{t}$ values are inadequate to determine whether differences are significant (Norusis, 1993). 


\section{NOTE DI LAVORO DELLA FONDAZIONE ENI ENRICO MATTEI \\ Fondazione Eni Enrico Mattei Working Papers Series \\ Our working papers are available on the Internet at the following addresses: \\ Server WWW: WWW.FEEM.IT \\ Anonymous FTP: FTP.FEEM.IT \\ To order any of these papers, please fill out the form at the end of the list.}

\begin{tabular}{|c|c|c|}
\hline CLIM & 1.2000 & $\begin{array}{l}\text { Claudia KEMFERT: The Impacts of Emissions Trading on World Economies. Contemplation of baseline } \\
\text { emissions paths and a ceiling on emissions trading }\end{array}$ \\
\hline CLIM & 2.2000 & scal FAVARD: Does Productive Capital Affect the Order of Resource Exploitation? \\
\hline CLIM & 3.2000 & $\begin{array}{l}\text { Robert T. DEACON (xxxix): The Political Economy of Environment-Development Relationships: A } \\
\text { Preliminary Framework }\end{array}$ \\
\hline SUST & 4.2000 & $\begin{array}{l}\text { Piet RIETVELD and Roberto ROSON: Joint Costs in Network Services: the Two-way Problem in the Case } \\
\text { of Unbalanced Transport Markets }\end{array}$ \\
\hline CLIM & 5.2000 & Robert S. PINDYCK (xxxix): Irreversibilities and the Timing of Environmental Policy \\
\hline MGMT & 6.2000 & $\begin{array}{l}\text { Domenico SINISCALCO, Stefania BORGHINI, Marcella FANTINI and Federica RANGHIERI (xl): The } \\
\text { Response of Companies to Information-Based Environmental Policies }\end{array}$ \\
\hline SUST & 7.2000 & $\begin{array}{l}\text { Guy D. GARROD, Riccardo SCARPA and Ken G. WILLIS: Estimating the Benefits of Traffic Calming on } \\
\text { Through Routes: A Choice Experiment Approach }\end{array}$ \\
\hline CLIM & 8.2000 & ZhongXiang ZHANG: Estimating the Size of the Potential Market for the Kyoto Flexibility Mechanisms \\
\hline VOL & 9.2000 & $\begin{array}{l}\text { Jean-Christophe PEREAU and Tarik TAZDAIT (xli): Partial and Global Cooperation with Unilateral } \\
\text { Commitment in the Presence of Global Environmental Problems }\end{array}$ \\
\hline KNOW & 10.2000 & $\begin{array}{l}\text { Giacomo CALZOLARI and Giovanni IMMORDINO: Hormone Beefs, Chloridric Chicken and International } \\
\text { Trade: Can Scientific Uncertainty be an Informational Barrier to Trade? }\end{array}$ \\
\hline CLIM & 11.2000 & $\begin{array}{l}\text { Laura MARSILIANI and Thomas I. RENSTRÖM (xxxvi): Imperfect Competition, Labour Market } \\
\text { Distortions, and the Double Dividend Hypothesis }\end{array}$ \\
\hline KNOW & 12.2000 & $\begin{array}{l}\text { Patrizia BUSSOLI : An Empirical Analysis of Technological Convergence Process and RJVs in Europe at } \\
\text { the Firm Level }\end{array}$ \\
\hline KNOW & 13.2000 & $\begin{array}{l}\text { Luigi BENFRATELLO and Alessandro SEMBENELLI: Research Joint Ventures and Firm Level } \\
\text { Performance }\end{array}$ \\
\hline NOW & 2000 & icholas S. VONORTAS: US Policy towards Research Joint Ventures \\
\hline ETA & 15.2000 & Effects of Emissions Standards on Industry in the Short Run and Long Run \\
\hline ETA & 16.2000 & Francis BLO \\
\hline CLIM & 17.2000 & $\begin{array}{l}\text { Giovanni IMMORDINO: Looking for a Guide to Protect the Environment: the Development of the } \\
\text { Precautionary Principle }\end{array}$ \\
\hline CLIM & 8.2000 & R: Negotiation and Optimality in an Economic Model of Global Climate Change \\
\hline VOL & 19.2000 & $\begin{array}{l}\text { Paola MILIZIA and Marialuisa TAMBORRA: Juridical Framework of Voluntary Agreements in Italy and } \\
\text { Policy Relevance at the Local Level }\end{array}$ \\
\hline CLIM & 20.2000 & $\begin{array}{l}\text { Richard S.J. TOL, Wietze LISE and Bob van der ZWAAN (xli): Technology Diffusion and the Stability of } \\
\text { Climate Coalitions }\end{array}$ \\
\hline CLIM & 21.2000 & $\begin{array}{l}\text { Pietro TEATINI and Giuseppe GAMBOLATI (xlii): The Impact of Climate Change, Sea-Storm Events and } \\
\text { Land Subsidence in the Adriatic }\end{array}$ \\
\hline CLIM & 22.2000 & $\begin{array}{l}\text { Emiliano RAMIERI (xlii): An Overview of the Vulnerability of Venice to the Impacts of Climate Change } \\
\text { and Sea Level Rise }\end{array}$ \\
\hline PRIV & 23.2000 & $\begin{array}{l}\text { Bernardo BORTOLOTTI, Marcella FANTINI and Carlo SCARPA: Why do Governments Sell Privatised } \\
\text { Companies Abroad? }\end{array}$ \\
\hline ETA & 24.2000 & $\begin{array}{l}\text { Carlo CARRARO and Gilbert E. METCALF: Behavioral and Distributional Effects of Environmental } \\
\text { Policy: Introduction }\end{array}$ \\
\hline ETA & 2000 & AZNAR: Sustainable Growth and Enviro \\
\hline KNOW & 26.2000 & Francesca RECANATINI and Randi RYTERMAN: Disorganisation or Self-Organisation? \\
\hline KNOW & 27.2000 & $\begin{array}{l}\text { Giorgio BARBA NAVARETTI and David TARR: International Knowledge Flows and Economic } \\
\text { Performance. An Introductory Survey of the Evidence }\end{array}$ \\
\hline SUST & 28.2000 & Francesca CODA CANATI: Secondary Raw Materials Market Creation: Waste Stock Exchange \\
\hline KNOW & 29.2000 & $\begin{array}{l}\text { Giorgio BRUNELLO and Simona COMI: Education and Earnings Growth. Evidence from } 11 \text { European } \\
\text { Countries }\end{array}$ \\
\hline CLIM & & Michael GRUBB: The Kyoto Protocol: an Eco \\
\hline CLIM & 31.2000 & $\begin{array}{l}\text { Gérard MONDELLO and Mabel TIDBALL (xxxix): Environmental Liability and Technology Choice: A } \\
\text { Duopolistic Analysis }\end{array}$ \\
\hline
\end{tabular}


KNOW 32.2000 Alberto PETRUCCI and Edmund PHELPS: Capital Subsidies Versus Labour Subsidies: A Trade-Off between Capital and Employment?

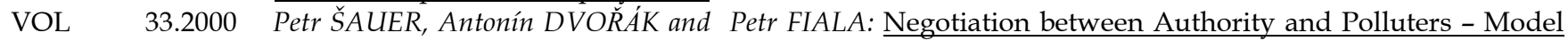
for Support of Decision Making in Environmental Policy: Principles and Experimental Case Test

SUST $\quad 34.2000 \quad$ Riccardo SCARPA, George W. HUTCHINSON and Sue M. CHILTON: Reliability of Benefit Value Transfers from Contingent Valuation Data with Forest-Specific Attributes

CLIM

35.2000

Allen PERRY (xlii): Impact of Climate Change on Tourism in the Mediterranean: Adaptive Responses

CLIM

36.2000 Laura MARSILIANI and T.I. RENGSTRÖM (xxxvi): Inequality, Environmental Protection and Growth

CLIM

37.2000 Massimiliano MONTINI (xlii): Italian Policies and Measures to Respond to Climate Change

CLIM $\quad 38.2000$ Horst STERR, Richard KLEIN and Stefan REESE (xlii): Climate Change and Coastal Zones. An Overview of the State-of-the-Art on Regional and Local Vulnerability Assessment

CLIM

39.2000

Tullio SCOVAZZI (xlii): Ideas Behind the New or Updated Mediterranean Legal Instruments

CLIM

40.2000

Dimitrios GEORGAS (xlii): Assessment of Climatic Change Impacts on Coastal Zones in the Mediterranean. UNEP's Vulnerability Assessments Methodology and Evidence from Case Studies

SUST

41.2000

Herath M. GUNATILAKE and Ujjayant CHAKRAVORTY: Forest Resource Extraction by Local Communities: A Comparative Dynamic Analysis

PRIV

42.2000 Giancarlo SPAGNOLO: Optimal Leniency Programs

CLIM

Paolo BUONANNO, Carlo CARRARO, Efrem CASTELNUOVO and Marzio GALEOTTI: Emission Trading Restrictions with Endogenous Technological Change

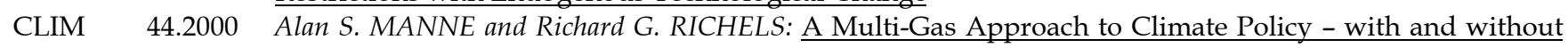
GWPs

WAT

45.2000

Ujjayant

CLIM

46.2000

Don FULLERTON, Inkee HONG and Gilbert E. METCALF (xl): A Tax on Output of the Polluting Industry is not a Tax on Pollution: The Importance of Hitting the Target

PRIV

47.2000

Axel GAUTIER and Dimitri PAOLINI: Delegation and Information Revelation

ETA

48.2000

Andreas PAPANDREOU: Externality, Convexity and Institutions

ETA

49.2000

Cesare DOSI and Michele MORETTO: The Timing of Adoption of Cleaner Technologies: Private Costs and Public Incentives

ETA

50.2000

Michele MORETTO and Roberto TAMBORINI: Liquidity: What can a "Hausbank" do that Other Lenders Cannot Do?

PRIV

51.2000 Michele MORE

PRIV

52.2000

Giancarlo SPAGNOLO: Self-Defeating Antitrust Laws

PRIV 53.2000

William L. MEGGINSON and Maria K. BOUTCHKOVA: The Impact of Privatisation on Capital Market Development and Individual Share Ownership

KNOW 54.2000 Giorgio BARBA NAVARETTI, Marzio GALEOTTI and Andrea MATTOZZI: Moving Skills from Hands to Heads: Import of Technology and Export Performance

ETA 55.2000 Elisabetta STRAZZERA, Riccardo SCARPA, Pinuccia CALIA, Guy GARROD and Ken WILLIS: Modelling Zero Bids in Contingent Valuation Surveys

CLIM $56.2000 \quad$ Paola CONCONI: Can Green Lobbies Replace a World Environmental Organisation?

VOL $57.2000 \quad$ Paola CONCONI and Carlo PERRONI (xli) : Issue Linkage and Issue Tie-in in Multilateral Negotiations

ETA 58.2000 Fernando JARAMILLO, Hubert KEMPF and Fabien MOIZEAU (xli): Conspicuous Consumption, Social $\underline{\text { Status and Clubs }}$

SUST $\quad 59.2000$ Gianni CICIA and Riccardo SCARPA: Willingness to Pay for Rural Landscape Preservation: A Case Study in Mediterranean Agriculture

CLIM $60.2000 \quad$ Josef JANSSEN: Will Joint Implementation Survive International Emissions Trading? Distinguishing the Kyoto Mechanisms

CLIM 61.2000 Carlo CARRARO: Costs, Structure and Equity of International Regimes for Climate Change Mitigation

KNOW 62.2000 Alberto BUCCI: On Scale Effects, Market Power and Growth when Human and Technological Capital are Complements

KNOW $63.2000 \quad \overline{\text { Alberto BUCCI }}$ and H.C. SAGLAM: Growth Maximising Patent Lifetime

WAT 64.2000

WAT 65.2000

Michele MORETTO and Paolo ROSATO: The Value of Licences for Recreational Resources Use

KNOW

66.2000

CLIM

67.2000

CAI DEFRANCESCO and Paolo ROSATO: Recreation Management in Venice Lagoon

Carlo DELL'ARINGA and Claudio LUCIFORA: Inside the Black Box: Labour Market Institutions, Wage Formation and Unemployment in Italy

Generations Economy without Capital

CLIM

68.2000 A. Lans BOVENBERG and Lawrence H. GOULDER (xl): Neutralising the Adverse Industry Impacts of $\mathrm{CO} 2$ Abatement Policies: What Does it Cost?

KNOW $69.2000 \quad$ Ioanna KASTELLI: Science and Technology Policy in Greece. Policy Initiatives for R\&D Cooperation

CLIM 70.2000 Katrin MILLOCK: Contracts for Clean Development - The Role of Technology Transfers

VOL 71.2000 Alberto CAVALIERE and Fabio FRONTOSO SILVESTRI (xliii): Voluntary Agreements as Information Sharing Devices: Competition and Welfare Effects 
VOL 72.2000 Na Li DAWSON and Kathleen SEGERSON (xliii): Voluntary Agreements with Industries: Participation Incentives with Industry-wide Targets

VOL 73.2000 Patricia M. BAILEY (xliii): The Application of Competition Law and Policy to Environmental Agreements in an Oligopolistic Market

VOL 74.2000 Joanna POYAGO-THEOTOKY (xliii): Voluntary Approaches and the Organisation of Environmental $\underline{R \& D}$

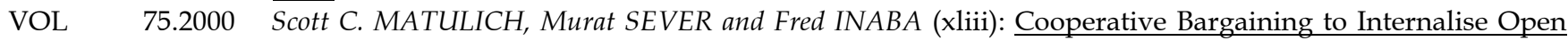
Access Externalities: Implications of the American Fisheries Act

VOL $\quad 76.2000$ Allen BLACKMAN and James BOYD (xliii): Tailored Regulation: Will Voluntary Site-Specific Environmental Performance Standards Improve Welfare?

VOL $\quad 77.2000 \quad$ Vincenzo DENICOLO' (xliii): A Signaling Model of Environmental Overcompliance

VOL 78.2000 Markus A. LEHMANN (xliii): Voluntary Environmental Agreements and Competition Policy. The Case of Germany's Private System for Packaging Waste Recycling

VOL $\quad 79.2000 \quad$ Hans H.B. VEDDER (xliii): Voluntary Agreements and Competition Law

VOL 80.2000 Thomas P. LYON and John W. MAXWELL (xliii): Self-Regulation, Taxation and Public Voluntary Environmental Agreements

VOL 81.2000 Paola MANZINI and Marco MARIOTTI (xliii): A Bargaining Model of Voluntary Environmental Agreements

VOL

CLIM

82.2000

Alain NADAI and Benoit MOREL (xliii): Product Ecolabelling, Competition and the Environment

KNOW 84.2000

Simone BORGHESI: Income Inequality and the Environmental Kuznets Curve

School Design

KNOW 85.2000 Giorgio BRUNELLO, Simona COMI and Claudio LUCIFORA: The College Wage Gap in 10 European Countries: Evidence from Two Cohorts?

ETA 86.2000 Michael FINUS: Game Theory and International Environmental Co-operation: A Survey with an Application to the Kyoto-Protocol

CLIM 87.2000 Clare GOODESS, Jean PALUTIKOF and Maureen AGNEW (xlii): Climate Change Scenarios for the Mediterranean: A Basis for Regional Impact Assessment

CLIM 88.2000 Ian COXHEAD: Tax Reform and the Environment in Developing Economies: Is a Double Dividend Possible?

SUST 89.2000 Peter BARTELMUS and André VESPER (xliv): Green Accounting and Material Flow Analysis. Alternatives or Complements?

SUST 90.2000 Mark DE HAAN and Steven J. KEUNING (xliv): The NAMEA as Validation Instrument for Environmental Macroeconomics

SUST 91.2000 Jochen JESINGHAUS (xliv): On the Art of Aggregating Apples \& Oranges

SUST $\quad 92.2000 \quad J a n$ KOLAR (xliv): Land Cover Accounting in the Czech Republic

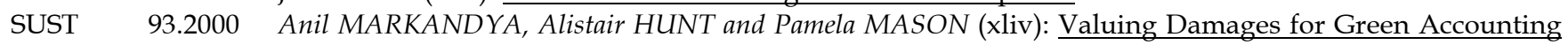
Purposes: The GARP II Approach

SUST 94.2000 Anil MARKANDYA, Pamela MASON and Marialuisa TAMBORRA (xliv): Green National Accounting: Synthesising and Extending the Welfare Based and Sustainability-standard Based Approaches

SUST $\quad 95.2000$ Martin O'CONNOR (xliv): Towards a Typology of "Environmentally-Adjusted" National Sustainability Indicators: Key Concepts and Policy Application

SUST $\quad 96.2000 \quad$ Anton STEURER (xliv): Towards an Environmental Accounting Framework for the EU

SUST 97.2000 Cesare COSTANTINO, Federico FALCITELLI and Angelica TUDINI (xliv): New Developments in Environmental Accounting at Istat

CLIM 98.2000 Stefan BAYER and Claudia KEMFERT: Reaching National Kyoto-Targets in Germany by Maintaining a Sustainable Development

CLIM 99.2000 ZhongXiang ZHANG: An Assessment of the EU Proposal for Ceilings on the Use of Kyoto Flexibility Mechanisms

KNOW 100.2000 Maria Rosa BATTAGGION and Patrizia BUSSOLI: Italian Policy towards Cooperation in R\&D

KNOW 101.2000 Giorgio BARBA NAVARETTI, Patrizia BUSSOLI, Georg VON GRAEVENITZ and David ULPH: Information Sharing, Research Coordination and Membership of Research Joint Ventures

WAT 102.2000 Cesare DOSI and William K. EASTER: Water Scarcity: Institutional Change, Water Markets and Privatisation

WAT $\quad 103.2000 \quad \overline{\text { Cesare DOSI and Naomi ZEITOUNI: Controlling Groundwater Pollution from Agricultural Nonpoint }}$ Sources: An Overview of Policy Instruments

KNOW 104.2000 Alberto PETRUCCI: On Debt Neutrality in the Savers-Spenders Theory of Fiscal Policy

SUST 105.2000 Roberto ROSON and Stefano SORIANI: Intermodality and the Changing Role of Nodes in Transport Networks

CLIM 106.2000 Alain BOUSQUET and Pascal FAVARD: Does S. Kuznets' Belief Question the Environmental Kuznets Curves?

CLIM $\quad 107.2000 \quad$ Ottavio JANNI: EU Biodiversity Conservation in Tropical Countries 
VOL $\quad 108.2000$ Katrin MILLOCK and François SALANIE: Collective Environmental Agreements: An Analysis of the Problems of Free-Riding and Collusion

VOL $\quad 109.2000 \quad$ Katrin MILLOCK: The Combined Use of Taxation and Voluntary Agreements for Energy Policy

VOL 110.2000 Markus A. LEHMANN: The Impact of Voluntary Environmental Agreements on Firms' Incentives for Technology Adoption

SUST $\quad 1.2001 \quad$ Inge MAYERES and Stef PROOST: Should Diesel Cars in Europe be Discouraged?

SUST 2.2001 Paola DORIA and Davide PETTENELLA: The Decision Making Process in Defining and Protecting Critical Natural Capital

CLIM $3.2001 \quad$ Alberto PENCH: Green Tax Reforms in a Computable General Equilibrium Model for Italy

CLIM 4.2001 Maurizio BUSSOLO and Dino PINELLI: Green Taxes: Environment, Employment and Growth

CLIM 5.2001 Marco STAMPINI: Tax Reforms and Environmental Policies for Italy

ETA 6.2001 Walid OUESLATI: Environmental Fiscal Policy in an Endogenous Growth Model with Human Capital

CLIM 7.2001 Umberto CIORBA, Alessandro LANZA and Francesco PAULI: Kyoto Commitment and Emission Trading: a European Union Perspective

MGMT 8.2001 Brian SLACK (xlv): Globalisation in Maritime Transportation: Competition, uncertainty and implications for port development strategy

VOL 9.2001 Giulia PESARO: Environmental Voluntary Agreements: A New Model of Co-operation Between Public and Economic Actors

VOL 10.2001 Cathrine HAGEM: Climate Policy, Asymmetric Information and Firm Survival

ETA 11.2001 Sergio CURRARINI and Marco MARINI: A Sequential Approach to the Characteristic Function and the Core in Games with Externalities

ETA 12.2001 Gaetano BLOISE, Sergio CURRARINI and Nicholas KIKIDIS: Inflation and Welfare in an OLG Economy with a Privately Provided Public Good

KNOW 13.2001 Paolo SURICO: Globalisation and Trade: A “New Economic Geography” Perspective

ETA $14.2001 \quad$ Valentina BOSETTI and Vincenzina MESSINA: Quasi Option Value and Irreversible Choices

CLIM 15.2001 Guy ENGELEN (xlii): Desertification and Land Degradation in Mediterranean Areas: from Science to Integrated Policy Making

SUST 16.2001 Julie Catherine SORS: Measuring Progress Towards Sustainable Development in Venice: A Comparative Assessment of Methods and Approaches

SUST 17.2001 Julie Catherine SORS: Public Participation in Local Agenda 21: A Review of Traditional and Innovative $\underline{\text { Tools }}$

CLIM 18.2001 Johan ALBRECHT and Niko GOBBIN: Schumpeter and the Rise of Modern Environmentalism

VOL 19.2001 Rinaldo BRAU, Carlo CARRARO and Giulio GOLFETTO (xliii): Participation Incentives and the Design of Voluntary Agreements

ETA $20.2001 \quad$ Paola ROTA: Dynamic Labour Demand with Lumpy and Kinked Adjustment Costs

ETA 21.2001 Paola ROTA: Empirical Representation of Firms' Employment Decisions by an (S,s) Rule

ETA 22.2001 Paola ROTA: What Do We Gain by Being Discrete? An Introduction to the Econometrics of Discrete Decision Processes

PRIV 23.2001 Stefano BOSI, Guillaume GIRMANS and Michel GUILLARD: Optimal Privatisation Design and Financial Markets

KNOW 24.2001 Giorgio BRUNELLO, Claudio LUPI, Patrizia ORDINE, and Maria Luisa PARISI: Beyond National Institutions: Labour Taxes and Regional Unemployment in Italy

ETA 25.2001 Klaus CONRAD: Locational Competition under Environmental Regulation when Input Prices and Productivity Differ

PRIV 26.2001 Bernardo BORTOLOTTI, Juliet D'SOUZA, Marcella FANTINI and William L. MEGGINSON: Sources of Performance Improvement in Privatised Firms: A Clinical Study of the Global Telecommunications Industry

CLIM 27.200

Frédéric BROCHIER and Emiliano RAMIERI: Climate Change Impacts on the Mediterranean Coastal Zones

ETA 28.2001 Nunzio CAPPUCCIO and Michele MORETTO: Comments on the Investment-Uncertainty Relationship in a Real Option Model

KNOW 29.2001 Giorgio BRUNELLO: Absolute Risk Aversion and the Returns to Education

CLIM 30.2001 ZhongXiang ZHANG: Meeting the Kyoto Targets: The Importance of Developing Country Participation

ETA 31.2001 Jonathan D. KAPLAN, Richard E. HOWITT and Y. Hossein FARZIN: An Information-Theoretical Analysis of Budget-Constrained Nonpoint Source Pollution Control

MGMT 32.2001 Roberta SALOMONE and Giulia GALLUCCIO: Environmental Issues and Financial Reporting Trends

Coalition

Theory 33.2001

Network

ETA $\quad 34.2001$

Shlomo WEBER and Hans WIESMETH: From Autarky to Free Trade: The Impact on Environment

Margarita GENIUS and Elisabetta STRAZZERA: Model Selection and Tests for Non Nested Contingent Valuation Models: An Assessment of Methods 
NRM 35.2001 Carlo GIUPPONI: The Substitution of Hazardous Molecules in Production Processes: The Atrazine Case Study in Italian Agriculture

KNOW 36.2001 Raffaele PACI and Francesco PIGLIARU: Technological Diffusion, Spatial Spillovers and Regional Convergence in Europe

PRIV 37.2001 Bernardo BORTOLOTTI: Privatisation, Large Shareholders, and Sequential Auctions of Shares

CLIM 38.2001 Barbara BUCHNER: What Really Happened in The Hague? Report on the COP6, Part I, 13-25 November 2000, The Hague, The Netherlands

PRIV 39.2001 Giacomo CALZOLARI and Carlo SCARPA: Regulation at Home, Competition Abroad: A Theoretical Framework

KNOW 40.2001 Giorgio BRUNELLO: On the Complementarity between Education and Training in Europe

Coalition 41.2001 Alain DESDOIGTS and Fabien MOIZEAU (xlvi): Multiple Politico-Economic Regimes, Inequality and

Theory

Network

Coalition 42.2001 Growth

Theory

Network

Coalition 43.2001

Theory

Network

Coalition 44.2001

Parkash CHANDER and Henry TULKENS (xlvi): Limits to Climate Change

Theory

Network

NRM 45.2001 Mohamad R. KHAWLIE (xlvii): The Impacts of Climate Change on Water Resources of LebanonEastern Mediterranean

NRM 46.2001 Mutasem EL-FADEL and E. BOU-ZEID (xlvii): Climate Change and Water Resources in the Middle East: Vulnerability, Socio-Economic Impacts and Adaptation

NRM

47.2001 Eva IGLESIAS, Alberto GARRIDO and Almudena GOMEZ (xlvii): An Economic Drought Management Index to Evaluate Water Institutions' Performance Under Uncertainty and Climate Change

CLIM 48.2001 Wietze LISE and Richard S.J. TOL (xlvii): Impact of Climate on Tourist Demand

CLIM 49.2001 Francesco BOSELLO, Barbara BUCHNER, Carlo CARRARO and Davide RAGGI: Can Equity Enhance Efficiency? Lessons from the Kyoto Protocol

SUST $50.2001 \quad$ Roberto ROSON (xlviii): Carbon Leakage in a Small Open Economy with Capital Mobility

SUST 51.2001 Edwin WOERDMAN (xlviii): Developing a European Carbon Trading Market: Will Permit Allocation Distort Competition and Lead to State Aid?

SUST 52.2001 Richard N. COOPER (xlviii): The Kyoto Protocol: A Flawed Concept

SUST 53.2001 Kari KANGAS (xlviii): Trade Liberalisation, Changing Forest Management and Roundwood Trade in Europe

SUST 54.2001 Xueqin ZHU and Ekko VAN IERLAND (xlviii): Effects of the Enlargement of EU on Trade and the Environment

SUST 55.2001 M. Ozgur KAYALICA and Sajal LAHIRI (xlviii): $\underline{\text { Strategic Environmental Policies in the Presence of }}$ Foreign Direct Investment

SUST 56.2001 Savas ALPAY (xlviii): Can Environmental Regulations be Compatible with Higher International Competitiveness? Some New Theoretical Insights

SUST 57.2001 Roldan MURADIAN, Martin O'CONNOR, Joan MARTINEZ-ALER (xlviii): Embodied Pollution in Trade: Estimating the "Environmental Load Displacement" of Industrialised Countries

SUST 58.2001 Matthew R. AUER and Rafael REUVENY (xlviii): Foreign Aid and Direct Investment: Key Players in the Environmental Restoration of Central and Eastern Europe

SUST 59.2001 Onno J. KUIK and Frans H. OOSTERHUIS (xlviii): Lessons from the Southern Enlargement of the EU for the Environmental Dimensions of Eastern Enlargement, in particular for Poland

ETA 60.2001 Carlo CARRARO, Alessandra POME and Domenico SINISCALCO (xlix): Science vs. Profit in Research: Lessons from the Human Genome Project

CLIM 61.2001 Efrem CASTELNUOVO, Michele MORETTO and Sergio VERGALLI: Global Warming, Uncertainty and Endogenous Technical Change: Implications for Kyoto

PRIV 62.2001 Gian Luigi ALBANO, Fabrizio GERMANO and Stefano LOVO: On Some Collusive and Signaling Equilibria in Ascending Auctions for Multiple Objects

CLIM 63.2001 Elbert DIJKGRAAF and Herman R.J. VOLLEBERGH: $\underline{\text { A Note on Testing for Environmental Kuznets }}$ Curves with Panel Data

CLIM 64.2001 Paolo BUONANNO, Carlo CARRARO and Marzio GALEOTTI: Endogenous Induced Technical Change and the Costs of Kyoto

CLIM 65.2001 Guido CAZZAVILLAN and Ignazio MUSU (1): Transitional Dynamics and Uniqueness of the BalancedGrowth Path in a Simple Model of Endogenous Growth with an Environmental Asset

CLIM 66.2001 Giovanni BAIOCCHI and Salvatore DI FALCO (1): Investigating the Shape of the EKC: A Nonparametric $\underline{\text { Approach }}$ 
CLIM 67.2001 Marzio GALEOTTI, Alessandro LANZA and Francesco PAULI (1): Desperately Seeking (Environmental) Kuznets: A New Look at the Evidence

CLIM 68.2001 Alexey VIKHLYAEV (xlviii): The Use of Trade Measures for Environmental Purposes - Globally and in the EU Context

NRM 69.2001 Gary D. LIBECAP and Zeynep K. HANSEN (li): U.S. Land Policy, Property Rights, and the Dust Bowl of the 1930s

NRM 70.2001 Lee J. ALSTON, Gary D. LIBECAP and Bernardo MUELLER (li): Land Reform Policies, The Sources of Violent Conflict and Implications for Deforestation in the Brazilian Amazon

CLIM 71.2001 Claudia KEMFERT: Economy-Energy-Climate Interaction - The Model WIAGEM -

SUST 72.2001 Paulo A.L.D. NUNES and Yohanes E. RIYANTO: Policy Instruments for Creating Markets for Bodiversity: Certification and Ecolabeling

SUST 73.2001 Paulo A.L.D. NUNES and Erik SCHOKKAERT (lii): Warm Glow and Embedding in Contingent Valuation

SUST 74.2001 Paulo A.L.D. NUNES, Jeroen C.J.M. van den BERGH and Peter NIJKAMP (lii): Ecological-Economic Analysis and Valuation of Biodiversity

VOL 75.2001 Johan EYCKMANS and Henry TULKENS (li): Simulating Coalitionally Stable Burden Sharing Agreements for the Climate Change Problem

PRIV 76.2001 Axel GAUTIER and Florian HEIDER: What Do Internal Capital Markets Do? Redistribution vs. Incentives

PRIV 77.2001 Bernardo BORTOLOTTI, Marcella FANTINI and Domenico SINISCALCO: Privatisation around the World: New Evidence from Panel Data

ETA 78.2001 Toke S. AIDT and Jayasri DUTTA (li): Transitional Politics. Emerging Incentive-based Instruments in Environmental Regulation

ETA 79.2001 Alberto PETRUCCI: Consumption Taxation and Endogenous Growth in a Model with New Generations

ETA 80.2001 Pierre LASSERRE and Antoine SOUBEYRAN (li): A Ricardian Model of the Tragedy of the Commons

ETA 81.2001 Pierre COURTOIS, Jean Christophe PÉREAU and Tarik TAZDAÏT: An Evolutionary Approach to the Climate Change Negotiation Game

NRM 82.2001 Christophe BONTEMPS, Stéphane COUTURE and Pascal FAVARD: Is the Irrigation Water Demand Really Convex?

NRM $\quad 83.200$

Unai PASCUAL and Edward BARBIER: A Model of Optimal Labour and Soil Use with Shifting Cultivation

CLIM 84.2001 Jesper JENSEN and Martin Hvidt THELLE: What are the Gains from a Multi-Gas Strategy?

CLIM 85.2001 Maurizio MICHELINI (liii): IPCC “Summary for Policymakers" in TAR. Do its results give a scientific support always adequate to the urgencies of Kyoto negotiations?

CLIM $\quad 86.2001$

CLIM 87.2001

ETA $\quad 88.2001$

Claudia KEMFERT (liii): Economic Impact Assessment of Alternative Climate Policy Strategies

Cesare DOSI and Michele MORETTO: Global Warming and Financial Umbrellas $\begin{aligned} & \text { ETA } 89.2001 \text { Capital Heterogeneity: Does it Matter? Fundamental Q and Investment on a Panel of Italian Firms } \\ & \text { Efrem CASTELNUOVO and Paolo SURICO: Model Uncertainty, Optimal Monetary Policy and the } \\ & \text { Preferences of the Fed }\end{aligned}$

CLIM 90.2001 Umberto CIORBA, Alessandro LANZA and Francesco PAULI: Kyoto Protocol and Emission Trading: Does the US Make a Difference?

CLIM 91.2001 ZhongXiang ZHANG and Lucas ASSUNCAO: Domestic Climate Policies and the WTO

SUST 92.2001 Anna ALBERINI, Alan KRUPNICK, Maureen CROPPER, Nathalie SIMON and Joseph COOK (lii): The Willingness to Pay for Mortality Risk Reductions: A Comparison of the United States and Canada

SUST 93.2001 Riccardo SCARPA, Guy D. GARROD and Kenneth G. WILLIS (lii): Valuing Local Public Goods with Advanced Stated Preference Models: Traffic Calming Schemes in Northern England

CLIM 94.2001 Ming CHEN and Larry KARP: Environmental Indices for the Chinese Grain Sector

CLIM 95.2001 Larry KARP and Jiangfeng ZHANG: Controlling a Stock Pollutant with Endogenous Investment and Asymmetric Information

ETA $96.2001 \quad$ Michele MORETTO and Gianpaolo ROSSINI: On the Opportunity Cost of Nontradable Stock Options

SUST 97.2001 Elisabetta STRAZZERA, Margarita GENIUS, Riccardo SCARPA and George HUTCHINSON: The Effect of Protest Votes on the Estimates of Willingness to Pay for Use Values of Recreational Sites

NRM 98.2001 Frédéric BROCHIER, Carlo GIUPPONI and Alberto LONGO: Integrated Coastal Zone Management in the Venice Area - Perspectives of Development for the Rural Island of Sant'Erasmo

NRM 99.2001 Frédéric BROCHIER, Carlo GIUPPONI and Julie SORS: Integrated Coastal Management in the Venice Area - Potentials of the Integrated Participatory Management Approach

NRM 100.2001 Frédéric BROCHIER and Carlo GIUPPONI: Integrated Coastal Zone Management in the Venice Area A Methodological Framework

PRIV 101.2001 Enrico C. PEROTTI and Luc LAEVEN: Confidence Building in Emerging Stock Markets

CLIM 102.2001 Barbara BUCHNER, Carlo CARRARO and Igor CERSOSIMO: On the Consequences of the U.S. Withdrawal from the Kyoto/Bonn Protocol 
103.2001 Riccardo SCARPA, Simon ANDERSON, Adam DRUCKER and Veronica GOMEZ: Valuing Genetic Resources in Courtyard Economies: The Case of Creole Pig in Yucatan

SUST 104.2001 Riccardo SCARPA, E. RUTO, P. KRISTJANSON and M. RADENY: Valuing Genetic Resources in African Livestock: An Empirical Comparison of Stated and Revealed Preference Value Estimates

SUST $\quad 105.2001$ Clemens B.A. WOLLNY: The Need to Conserve Farm Animal Genetic Resources Through CommunityBased Management in Africa: Should Policy Makers be Concerned?

SUST 106.2001 J.T. KARUGIA, O.A. MWAI, R. KAITHO, Adam G. DRUCKER, C.B.A. WOLLNY and J.E.O. REGE: Economic Analysis of Crossbreeding Programmes in Sub-Saharan Africa: A Conceptual Framework and Kenyan Case Study

107.2001 W. AYALEW, J.M. KING, E. BURNS and B. RISCHKOWSKY: Economic Evaluation of Smallholder Subsistence Livestock Production: Lessons from an Ethiopian Goat Development Program

SUST 108.2001 Gianni CICIA, Elisabetta D'ERCOLE and Davide MARINO: Valuing Farm Animal Genetic Resources by Means of Contingent Valuation and a Bio-Economic Model: The Case of the Pentro Horse

SUST 109.2001 Clem TISDELL: Socioeconomic Causes of Loss of Animal Genetic Diversity: Analysis and Assessment

SUST 110.2001 M.A. JABBAR and M.L. DIEDHOU: Does Breed Matter to Cattle Farmers and Buyers? Evidence from $\underline{\text { West Africa }}$

(xxxvi) This paper was presented at the Second EFIEA Policy Workshop on "Integrating Climate Policies in the European Environment. Costs and Opportunities", organised by the Fondazione Eni Enrico Mattei on behalf of the European Forum on Integrated Environmental Assessment, Milan, March 4-6, 1999

(xxxvii) This paper was presented at the Fourth Meeting of the Coalition Theory Network organised by the Fondazione Eni Enrico Mattei, CORE of Louvain-la-Neuve and GREQAM of Marseille, Aix-en-Provence, January 8-9, 1999

(xxxviii) This paper was presented at the International Conference on "Trade and Competition in the WTO and Beyond" organised by the Fondazione Eni Enrico Mattei and the Department of International Studies of the University of Padua, Venice, December 4-5, 1998

(xxxix) This paper was presented at the $3^{\text {rd }}$ Toulouse Conference on Environment and Resource Economics, organised by Fondazione Eni Enrico Mattei, IDEI and INRA and sponsored by MATE on "Environment, Energy Uses and Climate Change", Toulouse, June 14-16, 1999

(xl) This paper was presented at the conference on "Distributional and Behavioral Effects of Environmental Policy" jointly organised by the National Bureau of Economic Research and Fondazione Eni Enrico Mattei, Milan, June 11-12, 1999

(xli) This paper was presented at the Fifth Meeting of the Coalition Theory Network organised by the Fondazione Eni Enrico Mattei and the CODE, Universitat Autonoma de Barcelona, Barcelona January 21-22, 2000

(xlii) This paper was presented at the International Workshop on "Climate Change and Mediterranean Coastal Systems: Regional Scenarios and Vulnerability Assessment" organised by the Fondazione Eni Enrico Mattei in co-operation with the Istituto Veneto di Scienze, Lettere ed Arti, Venice, December 9-10, 1999.

(xliii)This paper was presented at the International Workshop on "Voluntary Approaches, Competition and Competitiveness" organised by the Fondazione Eni Enrico Mattei within the research activities of the CAVA Network, Milan, May 25-26,2000.

(xliv) This paper was presented at the International Workshop on "Green National Accounting in Europe: Comparison of Methods and Experiences" organised by the Fondazione Eni Enrico Mattei within the Concerted Action of Environmental Valuation in Europe (EVE), Milan, March 4-7, 2000

(xlv) This paper was presented at the International Workshop on "New Ports and Urban and Regional Development. The Dynamics of Sustainability" organised by the Fondazione Eni Enrico Mattei, Venice, May 5-6, 2000.

(xlvi) This paper was presented at the Sixth Meeting of the Coalition Theory Network organised by the Fondazione Eni Enrico Mattei and the CORE, Université Catholique de Louvain, Louvain-la-Neuve, Belgium, January 26-27, 2001

(xlvii) This paper was presented at the RICAMARE Workshop "Socioeconomic Assessments of Climate Change in the Mediterranean: Impact, Adaptation and Mitigation Co-benefits", organised by the Fondazione Eni Enrico Mattei, Milan, February 9-10, 2001 (xlviii) This paper was presented at the International Workshop "Trade and the Environment in the Perspective of the EU Enlargement ", organised by the Fondazione Eni Enrico Mattei, Milan, May 17-18, 2001 
(xlix) This paper was presented at the International Conference "Knowledge as an Economic Good", organised by Fondazione Eni Enrico Mattei and The Beijer International Institute of Environmental Economics, Palermo, April 20-21, 2001

(l) This paper was presented at the Workshop "Growth, Environmental Policies and + Sustainability" organised by the Fondazione Eni Enrico Mattei, Venice, June 1, 2001

(li) This paper was presented at the Fourth Toulouse Conference on Environment and Resource Economics on "Property Rights, Institutions and Management of Environmental and Natural Resources", organised by Fondazione Eni Enrico Mattei, IDEI and INRA and sponsored by MATE, Toulouse, May 3-4, 2001

(lii) This paper was presented at the International Conference on "Economic Valuation of Environmental Goods", organised by Fondazione Eni Enrico Mattei in cooperation with CORILA, Venice, May 11, 2001

(liii) This paper was circulated at the International Conference on "Climate Policy - Do We Need a New Approach?", jointly organised by Fondazione Eni Enrico Mattei, Stanford

University and Venice International University, Isola di San Servolo, Venice, September 6-8, 2001

\section{SERIES}

MGMT Corporate Sustainable Management (Editor: Andrea Marsanich)

CLIM Climate Change Modelling and Policy (Editor: Marzio Galeotti )

PRIV Privatisation, Antitrust, Regulation (Editor: Bernardo Bortolotti)

KNOW Knowledge, Technology, Human Capital (Editor: Dino Pinelli)

WAT Water and Natural Resources Management (Editor: Carlo Giupponi)

SUST Sustainability Indicators and Impact Assessment (Editor: Marialuisa Tamborra)

VOL Task Force on Voluntary Agreements (Editor: Rinaldo Brau)

ETA Economic Theory and Applications (Editor: Carlo Carraro)

\section{SERIES}

MGMT Corporate Sustainable Management (Editor: Andrea Marsanich)

CLIM Climate Change Modelling and Policy (Editor: Marzio Galeotti )

PRIV Privatisation, Antitrust, Regulation (Editor: Bernardo Bortolotti)

KNOW Knowledge, Technology, Human Capital (Editor: Dino Pinelli)

NRM Natural Resources Management (Editor: Carlo Giupponi)

SUST Sustainability Indicators and Environmental Evaluation

(Editor: Marialuisa Tamborra)

VOL Voluntary and International Agreements (Editor: Carlo Carraro)

ETA Economic Theory and Applications (Editor: Carlo Carraro) 


\section{SUBSCRIPTION TO “NOTE DI LAVORO”}

Starting from January 1998 Fondazione Eni Enrico Mattei issues a Periodic E-mail "Note di Lavoro" Bulletin listing the titles and the abstracts of its most recent Working Papers.

All the "Note di Lavoro" listed in the Bulletin are available on the Internet and are downloadable from Feem's web site "www.feem.it".

If you wish to receive hard copies you may choose from the payment options listed in the following table (minimum order: 10 papers)*.

*Orders for individual papers should clearly indicate the "Nota di Lavoro" number and can therefore be issued for published papers only.

All orders must be sent by fax to:

"Publications Office" - Fondazione Eni Enrico Mattei: Fax +39+2+52036946

\section{PAYMENT OPTIONS}

\begin{tabular}{|l|l|l|}
\hline How many papers? & What's the price? & How to pay? \\
\hline 10 or more* & $\begin{array}{l}\text { US\$ 4.00 each } \\
\text { ITL 7,000 each }\end{array}$ & By Credit card or Bank transfer \\
\hline $\begin{array}{l}\text { Annual subscription } \\
\text { (approx. 100 papers/year) }\end{array}$ & $\begin{array}{l}\text { US\$ } 250.00 \\
\text { ITL 425,000 }\end{array}$ & By Credit card or Bank transfer \\
\hline
\end{tabular}

*Please fill out the Working Paper Subscription Form indicating your preferences

(Periodic E-mail "Note di Lavoro" Bulletin, Annual subscription, Order for individual papers - minimum 10*)!

\section{WORKING PAPER SUBSCRIPTION FORM}

Name:

Affiliation(if applicable):

Address:

Phone:

Fax:

E-mail:

I wish to:

Amount due:

Q receive the Periodic E-mail Working Papers Bulletin

¿ place a full annual subscription for 2001 (US\$ 250.00/ITL 425,000)

૫ order no......individual papers (minimum 10 papers at US $\$ 4.00 / I T L ~ 7,000$ each)*

Total

I will pay by:

૫ VISA $\square$ American Express Card No.___ Expiration Date:

Signature:

Bank transfer in US\$ (or Italian Lire in Italy) to Fondazione Eni Enrico Mattei - account no. 39341-56 -

SWIFT ARTIITM2 - ABI 03512 - CAB 01614 - Credito Artigiano - Corso Magenta 59, 20123 Milano, Italy.

Copy of the bank transfer should be faxed along with the order.

Please return this duly completed form to:

"Publications Office" - Fondazione Eni Enrico Mattei - Corso Magenta, 63 - 20123 Milano, Italy 